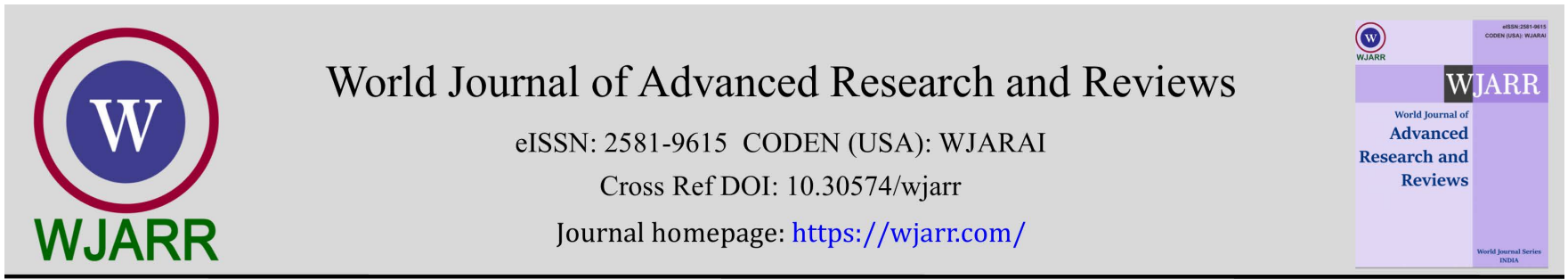

(RESEARCh ARTICLE)

Check for updates

\title{
Neonatal and maternal factors associated with hepatic dysfunction after birth asphyxia
}

\author{
Asmaa M Lafta ${ }^{1}$, Aida A Manther ${ }^{2}$ and Miami K Yousif 3,* \\ ${ }^{1}$ Department of Pediatrics, Mohammed Al Mousawi Hospital, Thi-qar. \\ 2 Department of Pediatrics, Basrah Medical College, University of Basrah. \\ ${ }^{3}$ Department of Pediatrics, Alzahraa Medical College, University of Basrah.
}

World Journal of Advanced Research and Reviews, 2021, 12(03), 264-270

Publication history: Received on 10 November 2021; revised on 13 December 2021; accepted on 15 December 2021

Article DOI: https://doi.org/10.30574/wjarr.2021.12.3.0696

\begin{abstract}
Background: Liver cell injury commonly occurs after perinatal asphyxia. This study aimed to identify the neonatal and maternal factors related to hepatic dysfunction associated with birth asphyxia.

Methods: A case control study was carried out in Basra comprising 43 asphyxiated newborns, and 57 healthy full terms enrolled as control. Serum levels of liver enzymes [alanine transferase (ALT), aspartate transferase (AST), alkaline phosphatase (ALP)] were measured and compared between the study and control groups. Levels beyond $+2 \mathrm{SD}$ above the mean of control considered high. Statistical analysis was done using SPSS program version 20. Chi-Square test and ANOVA were used where appropriate, $\mathrm{P}$-value $<0.05$ was considered as significant. Elevated levels of enzymes were studied in relation to selected neonatal and maternal variables.
\end{abstract}

Results: Higher levels of liver enzymes were found related to gestational age $>40$ weeks, newborn's body weight $>4$ $\mathrm{Kg}$, mother's age $>35$ years, parity $>4$ children and maternal medical disease. The results were statistically significant $(\mathrm{P}<0.05)$. However, no statistical differences were detected regarding newborn's gender and growth status, maternal education and mode of delivery.

Conclusion: The study highlights the relationship between maternal and neonatal risk factors and perinatal asphyxia associated with hepatic dysfunction.

Keywords: Aspartate; Control; Gender; Parity

\section{Introduction}

Perinatal asphyxia is defined as the failure to establish spontaneous breathing at birth [1, 2], leads to a transient interruption of oxygen availability that implies a risky metabolic challenge $[3,4]$. In developing countries neonatal mortality rate constitutes $42 \%$ of under-5 deaths $[5,6,7]$. According to a World Health Organization report, perinatal asphyxia is the third leading cause of under-5 child deaths (11\%) following preterm birth (17\%) and pneumonia (15\%) $[4,7,8]$. A correct definition of birth asphyxia requires assessment of cord blood $\mathrm{pH}$, Apgar score, neurological status, and markers of birth multi-organ function $[9,10]$. Hypoxia can cause damage to every tissue in the body. As a defense, the cardiac output is centralized to organs such as brain, heart and adrenals at the expense of less important organs such as liver, lungs, skin, kidney, muscles [11]. Liver cell injury commonly occurs after perinatal asphyxia, and it is represented as an early, abrupt, and transient increase in aminotransferases [aspartate transferase (AST) and alanine

\footnotetext{
* Corresponding author: Miami K Yousif

Department of Pediatrics, Alzahraa Medical College, University of Basrah.

Copyright $(2021$ Author(s) retain the copyright of this article. This article is published under the terms of the Creative Commons Attribution Liscense 4.0.
} 
transferase (ALT)], alkaline phosphatase (ALP), and lactate dehydrogenase (LDH) plasma activity· [12]. various factors are associated with the development of perinatal asphyxia with multi- organ involvement. This study aimed to identify neonatal and maternal risk factors for the occurrence of hepatic dysfunction in newborns with birth asphyxia.

\section{Methods}

Study design and subjects: A case- control study was conducted in the Intensive Neonatal Care Unit (NICU) in Basra Maternal and Children Hospital in 2016 for a period of 6 months (October- April) comprising 43 full-term newborns, 28 males (65\%) and 15 females (35\%) aged 1-10 days delivered with Apgar score $<7$ at 1 minute of life, acidemia ( PH<7) with no cry or delayed 5 minutes after birth [ the guidelines laid down by National- Neonatal perinatal data base network of India] [13] and neurological manifestations.

Excluded criteria: patients with major congenital anomaly, prematurity, sepsis, congenital infection, hemolytic condition and primary hepatobiliary disease. A total of 57 healthy full-term newborns, 31 males (54\%) and 26 females (46\%) enrolled as control group. Complete physical and neurologic examination performed for all subjects. Neonatal data included age, sex, gestational age, body weight and growth status, Apgar score at 1 and 5 minutes and outcome. According to fetal growth, patients were categorized in to: large for gestational age LGA (birth weight $>90$ th centile for gestational age), appropriate for gestational age AGA (birth weight $>10$ th $<90$ th centile for gestational age) and small for gestational age SGA (birth weight $<10$ th centile for gestational age). Detailed history was taken regarding maternal age, parity, educational level, antenatal care, and any history of medical problems. Regular antenatal care indicated by 10 appointments for nulliparous and 7 for multipara. Labor data included mode of delivery, history of prolonged labor ( $>24$ hours) or ruptured membrane (>18 hours), meconium-stained liquor, cord prolapse and others.

Serum levels of ALT, AST and ALP were measured in both study and control groups, levels beyond +2SD above the mean of control group were regarded as high. Statistical analysis was done using SPSS program version 20. Chi-Square test and ANOVA were used where appropriate, $\mathrm{P}$-value $<0.05$ was considered as significant.

\section{Results}

Mean serum level values (IU/L) for ALT (67.23 \pm 4.61 ), AST ( 89.02 \pm 7.99 ) and ALP ( 294.26 \pm 22.80 ) in asphyxiated

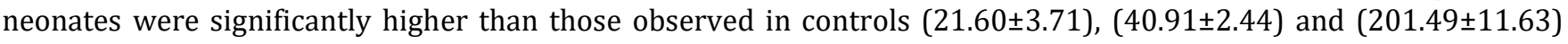
respectively $(\mathrm{P}<0.05)$.

High levels of ALT, AST and ALP were found in 38 (77.6\%), 31(68.9\%) and 24 (60\%) of patients respectively. The relation between high levels of liver enzymes and selected neonatal and maternal characteristics has been studied.

\subsection{Selected neonatal variables in relation to high levels of ALT, AST and ALP:}

High levels of enzymes were studied in relation to patient's sex, gestational age, and body weight and growth status. (Table 1,2.3).

Table 1 High ALT in relation to selected neonatal variables

\begin{tabular}{|l|l|l|c|c|}
\hline \multirow{2}{*}{\multicolumn{2}{|c|}{ Variable }} & \multicolumn{2}{c|}{ ALT(IU/L) } & \multirow{2}{*}{ P-value } \\
\cline { 2 - 4 } & Mean \pm SD & NO. \% & \\
\hline \multirow{3}{*}{ Sex } & Male & $93.45 \pm 67.81$ & 2463.20 & \multirow{2}{*}{$* 0.063$} \\
\cline { 2 - 4 } & Female & $81.23 \pm 73.90$ & 1436.80 & \\
\hline \multirow{3}{*}{$\begin{array}{l}\text { Gestational } \\
\text { Age (wks) }\end{array}$} & $37-38$ & $44.45 \pm 54.89$ & 3284.20 & \\
\cline { 2 - 4 } & $39-40$ & $74.33 \pm 56.98$ & 37.90 & \multirow{2}{*}{$* * 0.001$} \\
\cline { 2 - 4 } & $>40$ & $92.47 \pm 23.57$ & 37.90 & \\
\hline \multirow{3}{*}{$\begin{array}{l}\text { Growth } \\
\text { Status }\end{array}$} & LGA & $93.79 \pm 56.78$ & 1231.10 & \multirow{2}{*}{$* 0.081$} \\
\cline { 2 - 4 } & AGA & $88.24 \pm 45.91$ & 1539.00 & \multirow{2}{*}{0.080} \\
\cline { 2 - 4 } & SGA & $84.58 \pm 58.98$ & 1129.90 & \\
\hline
\end{tabular}




\begin{tabular}{|l|l|c|c|c|}
\hline \multirow{3}{*}{$\begin{array}{l}\text { Body weight } \\
(\mathrm{kg})\end{array}$} & $<2.5$ & $55.45 \pm 12.78$ & 821.10 & \multirow{2}{*}{$* 0.001$} \\
\cline { 2 - 4 } & $2.5-4$ & $67.45 \pm 61.89$ & $2873.70)$ & \multirow{2}{*}{0.00} \\
\cline { 2 - 4 } & $>4$ & $129.90 \pm 34.67$ & 25.20 & \\
\hline
\end{tabular}

Table 2 High AST in relation to selected neonatal variables

\begin{tabular}{|c|c|c|c|c|}
\hline \multirow{2}{*}{\multicolumn{2}{|c|}{ Variable }} & \multicolumn{2}{|l|}{ AST (IU/L) } & \multirow{2}{*}{$P$-value } \\
\hline & & \multirow{2}{*}{$\begin{array}{l}\text { Mean } \pm \text { SD } \\
94.45 \pm 55.81\end{array}$} & \multirow{2}{*}{$\begin{array}{c}\text { NO. \% } \\
2260.00\end{array}$} & \\
\hline \multirow{2}{*}{ Sex } & Male & & & \multirow{2}{*}{$* 0.072$} \\
\hline & Female & $81.23 \pm 88.93$ & 940.00 & \\
\hline \multirow{3}{*}{$\begin{array}{l}\text { Gestational } \\
\text { Age (wks) }\end{array}$} & $37-38$ & $53.45 \pm 66.81$ & 2683.90 & \multirow{3}{*}{ **0.001 } \\
\hline & $39-40$ & $74.88 \pm 56.90$ & 39.70 & \\
\hline & $>40$ & $123.47 \pm 23.57$ & 26.40 & \\
\hline \multirow{3}{*}{$\begin{array}{l}\text { Growth } \\
\text { Status }\end{array}$} & LGA & $114.79 \pm 23.30$ & 929.00 & \multirow{3}{*}{$* * 0.063$} \\
\hline & AGA & $94.24 \pm 45.91$ & 1445.20 & \\
\hline & SGA & $98.52 \pm 58.78$ & 825.80 & \\
\hline \multirow{3}{*}{$\begin{array}{l}\text { Body weight } \\
\text { (kg) }\end{array}$} & $<2.5$ & $43.45 \pm 12.78$ & 722.50 & \multirow{3}{*}{$* * 0.001$} \\
\hline & $2.5-4$ & $58.40 \pm 32.76$ & 2271.00 & \\
\hline & $>4$ & $119.70 \pm 94.22$ & 26.50 & \\
\hline
\end{tabular}

Table 3 High ALT in relation to selected neonatal variables

\begin{tabular}{|c|c|c|c|c|}
\hline \multirow{2}{*}{\multicolumn{2}{|c|}{ Variable }} & \multicolumn{2}{|l|}{ ALP(IU/L) } & \multirow[b]{2}{*}{ P-value } \\
\hline & & \multirow{2}{*}{$\begin{array}{l}\text { Mean } \pm \text { SD } \\
378.30 \pm 20.89\end{array}$} & \multirow{2}{*}{$\begin{array}{l}\text { NO. \% } \\
1562.50\end{array}$} & \\
\hline Sex & Male & & & \multirow[b]{2}{*}{$* 0.090$} \\
\hline & female & $356.23 \pm 87.83$ & 937.50 & \\
\hline \multirow{3}{*}{$\begin{array}{l}\text { Gestational } \\
\text { Age (wks) }\end{array}$} & $37-38$ & $213.90 \pm 56.31$ & 1875.00 & \multirow{3}{*}{${ }^{* *} 0.001$} \\
\hline & $39-40$ & $209.88 \pm 88.90$ & 312.50 & \\
\hline & $>40$ & $401.47 \pm 23.34$ & 312.50 & \\
\hline \multirow{3}{*}{$\begin{array}{l}\text { Growth } \\
\text { status }\end{array}$} & LGA & $353.23 \pm 67.36$ & 520.80 & \multirow{3}{*}{${ }^{* *} 0.172$} \\
\hline & AGA & $399.24 \pm 45.98$ & 1041.70 & \\
\hline & SGA & $310.33 \pm 58.44$ & 937.50 & \\
\hline \multirow{3}{*}{$\begin{array}{l}\text { Body weight } \\
(\mathrm{kg})\end{array}$} & $<2.5$ & $278.45 \pm 12.11$ & 833.30 & \multirow{3}{*}{${ }^{* *} 0.070$} \\
\hline & $2.5-4$ & $290.40 \pm 44.34$ & 1562.50 & \\
\hline & $>4$ & $310.30 .70 \pm 88.23$ & 14.20 & \\
\hline
\end{tabular}

\subsection{Selected maternal variables in relation to high levels of ALT, AST and ALP}

High levels of enzymes were studied in relation to maternal age, parity, educational level, antenatal care, and history of medical problems. Table $(4,5,6)$ 
Table 4 High ALT in relation to selected maternal variables

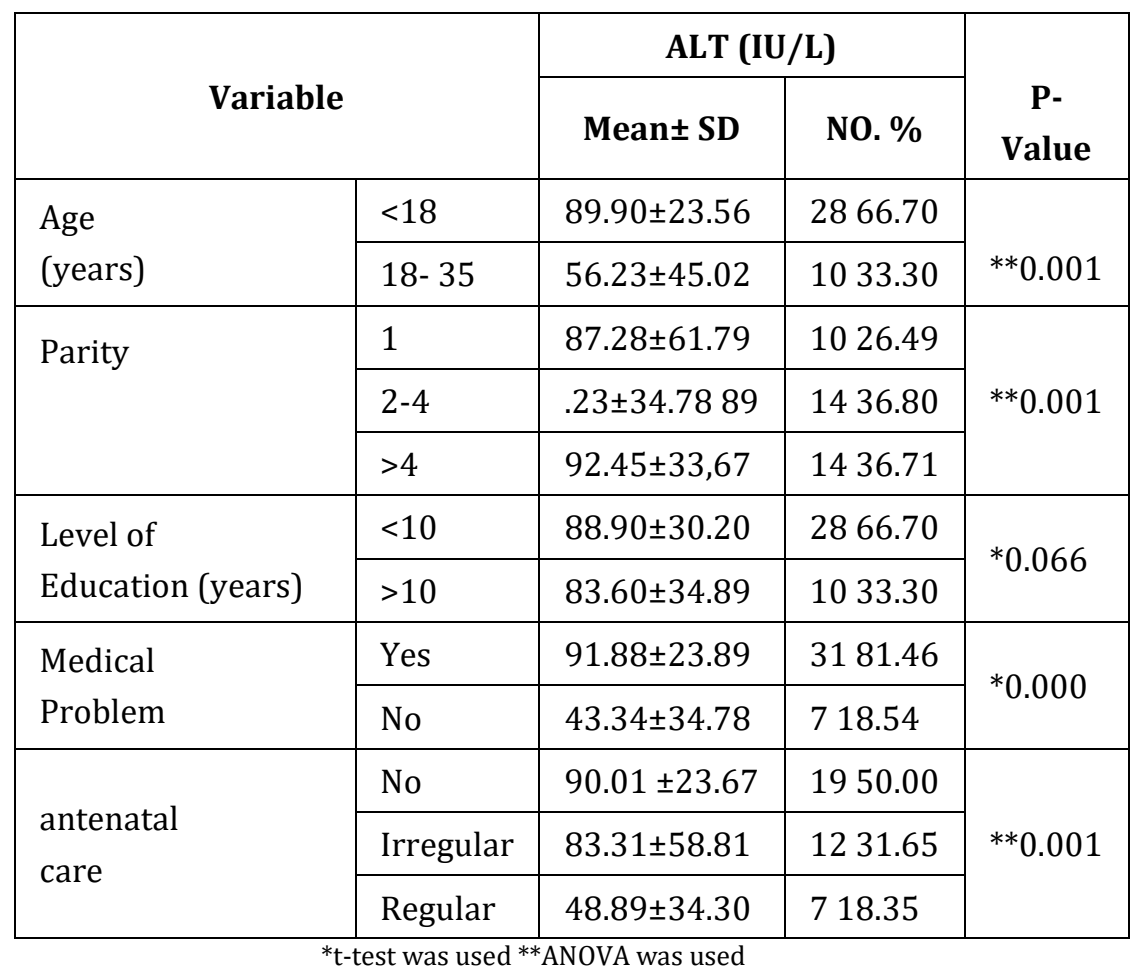

Table 5 High AST in relation to selected maternal variables

\begin{tabular}{|c|c|c|c|c|}
\hline \multirow{2}{*}{\multicolumn{2}{|c|}{ Variable }} & \multicolumn{2}{|l|}{ AST(IU/L) } & \multirow{2}{*}{$P$ value } \\
\hline & & \multirow{2}{*}{$\frac{\text { Mean } \pm \text { SD }}{66.90 \pm 42.02}$} & \multirow{2}{*}{$\begin{array}{l}\text { NO. \% } \\
722.60\end{array}$} & \\
\hline \multirow{3}{*}{$\begin{array}{l}\text { Age } \\
\text { (years) }\end{array}$} & $<18$ & & & \multirow{3}{*}{${ }^{* *} 0.001$} \\
\hline & 18- 35 & $94.23 \pm 25.40$ & 1961.30 & \\
\hline & $>35$ & $112.23 \pm 23.78$ & 516.10 & \\
\hline \multirow{3}{*}{ Parity } & 1 & $119.28 \pm 34.39$ & 825.84 & \multirow{3}{*}{$* * 0.001$} \\
\hline & $2-4$ & $65.23 \pm 34.78$ & 1341.96 & \\
\hline & $>4$ & $120.45 \pm 33.67$ & 1032.20 & \\
\hline \multirow{2}{*}{$\begin{array}{l}\text { Level of } \\
\text { Education (years) }\end{array}$} & $<10$ & $88.34 \pm 33.78$ & 2374.20 & \multirow{2}{*}{$* 0.134$} \\
\hline & $>10$ & $93.60 \pm 34.89$ & 825.80 & \\
\hline \multirow{2}{*}{$\begin{array}{l}\text { Medical } \\
\text { Problem }\end{array}$} & Yes & $100.88 \pm 51.89$ & 2477.40 & \multirow{2}{*}{$* 0.001$} \\
\hline & No & $62.34 \pm 62.79$ & 722.60 & \\
\hline \multirow{3}{*}{ antenatal care } & No & $110.01 \pm 23.67$ & 1651.60 & \multirow{3}{*}{$* * 0.781$} \\
\hline & Irregular & $83.31 \pm 51.55$ & 825.80 & \\
\hline & Regular & $880.89 \pm 41.23$ & 722.60 & \\
\hline
\end{tabular}


Table 6 High ALP in relation to selected maternal variables

\begin{tabular}{|c|c|c|c|c|}
\hline \multirow{2}{*}{\multicolumn{2}{|c|}{ Variable }} & \multicolumn{2}{|c|}{ ALP(IU/L) } & \multirow{2}{*}{ P-value } \\
\hline & & \multirow{2}{*}{$\begin{array}{c}\text { Mean } \pm \text { SD } \\
234.37 \pm 54.65\end{array}$} & \multirow{2}{*}{$\begin{array}{l}\text { NO. \% } \\
28.31\end{array}$} & \\
\hline \multirow{3}{*}{$\begin{array}{l}\text { Age } \\
\text { (years) }\end{array}$} & $<18$ & & & \multirow{3}{*}{$* * 0.001$} \\
\hline & $18-35$ & $388.13 \pm 50.34$ & 1666.69 & \\
\hline & $>35$ & $402.23 \pm 49.90$ & 625.00 & \\
\hline \multirow{3}{*}{ Parity } & 1 & $342.88 \pm 45.59$ & 520.81 & \multirow{3}{*}{$* * 0.161$} \\
\hline & $2-4$ & $360.21 \pm 33.45$ & 937.56 & \\
\hline & $>4$ & $410.45 \pm 33.55$ & 1041.63 & \\
\hline \multirow{2}{*}{$\begin{array}{l}\text { Level of Education } \\
\text { (years) }\end{array}$} & $<10$ & $267.90 \pm 45.79$ & 1979.20 & \multirow{2}{*}{$0.093^{*}$} \\
\hline & $>10$ & $281.34 \pm 56.89$ & 520.80 & \\
\hline \multirow{2}{*}{$\begin{array}{l}\text { Medical } \\
\text { Problem }\end{array}$} & Yes & $289.88 \pm 44.90$ & 1979.20 & \multirow{2}{*}{$0.123^{*}$} \\
\hline & No & $305.90 \pm 67.89$ & 520.80 & \\
\hline \multirow{3}{*}{ antenatal care } & No & $358.01 \pm 43.30$ & 1458.40 & \multirow{3}{*}{ **0.081 } \\
\hline & Irregular & $355.31 \pm 21.90$ & 520.80 & \\
\hline & Regular & $345.89 \pm 45.66$ & 520.80 & \\
\hline
\end{tabular}

\subsection{Relation between high levels of ALT, AST, ALP with mode of delivery and labor-problems}

The relation of high enzyme levels and mode of delivery and labor problems is shown in table 7

Table 7 High ALT, AST, ALP in relation to mode of delivery and labor problems

\begin{tabular}{|c|c|c|c|c|c|c|c|}
\hline \multicolumn{2}{|l|}{ Variable } & $\begin{array}{l}\text { ALT } \\
\text { Mean } \pm \text { SD }\end{array}$ & P-value & $\begin{array}{l}\text { AST } \\
\text { Mean } \pm \text { SD }\end{array}$ & P-value & $\begin{array}{l}\text { ALP } \\
\text { Mean } \pm \text { SD }\end{array}$ & P-value \\
\hline \multirow{2}{*}{ Mode of delivery } & $\mathrm{C} / \mathrm{S}$ & $51.67 \pm 31.67$ & \multirow{2}{*}{0.120} & $100.45 \pm 80.56$ & \multirow{2}{*}{0.89} & $280.34 \pm 34.78$ & \multirow{2}{*}{0.920} \\
\hline & ND & $63.45 \pm 35.45$ & & $91.78 \pm 23.78$ & & $291.45 \pm 45.89$ & \\
\hline \multirow{2}{*}{ Labor problem } & Present & $115.78 \pm 45$ & \multirow{2}{*}{0.031} & $100.34 \pm 98.34$ & \multirow{2}{*}{0.635} & $310.56 \pm 45.78$ & \multirow{2}{*}{0.161} \\
\hline & Absent & $61.67 \pm 34.89$ & & $94.89 \pm 34.67$ & & $289.67 \pm 45.78$ & \\
\hline
\end{tabular}

\section{Discussion}

Birth asphyxia can cause hepatic hypoxic cell damage. Aminotransferases are important tests for liver impairment. The current study aimed to identify the relation between the levels of hepatic enzymes after birth asphyxia and selected neonatal and maternal variables. Males outnumbered females in both study (65\%) and control (54\%) groups. This was similar to a study by Saboute et al [14]. The levels observed for serum liver enzymes were significantly higher in asphyxiated newborns than controls, a finding in agreement with similar studies $[12,15,16]$. The study showed a significant relation between increased levels of ALT, AST and ALP with gestational age ( $>40$ weeks) of asphyxiated newborns $(\mathrm{P}<0.05)$. However, there was no significant association with the gender and growth status. A study by Chhavi et al reported that SGA babies had significantly lower ALT and AST levels than AGA babies [16].

Elevated levels of ALT and AST showed significant association with newborn's body weight $(\mathrm{P}<0.05)$, while no significant difference was noted with ALP $(\mathrm{P}=0.071)$. Fetal birth weight $>4$ kilograms increases the risk of a variety of problems after birth. 
The influence of maternal factors has been studied. The study revealed significant association between rise in enzyme levels and advanced maternal age $(\mathrm{P}<0.05)$. Maternal age as young as 35 is a risk factor for multiple issues that can occur during pregnancy and delivery. Increased parity ( $>4$ children) was another factor related to high ALT and AST (P<0.05) but not ALP. In addition, we couldn't find any association between mothers' education and high enzymes. Only ALT showed a significant relation with no or irregular antenatal care. Regarding the association with maternal medical diseases like hypertension, diabetes, anemias, renal, cardiac or obstetric problems; ALT and AST showed significant results. The association with different modes of delivery and complication around labor was noted very minimal, only high ALT had relation with problems around labor. El-Kabbany et al, in their study, noticed significant increase in the frequency of asphyxia among those born by Cesarean section when compared to those born vaginally [17].

The study was limited by small- sized study population and short study period.

\section{Conclusion}

Neonatal and maternal risk factors for hepatic dysfunction associated with perinatal asphyxia included: large newborn's body weight $>4 \mathrm{~kg}$, gestational age $>40$ weeks, maternal age $>35$ years and in presence of maternal diseases.

\section{Compliance with ethical standards}

\section{Acknowledgments}

We extend our thanks to the patients' families and the health care providers in the Intensive Neonatal Care Unit (NICU) in Basra Maternal and Children Hospital.

\section{Disclosure of conflict of interest}

The authors declare that there is no conflict of interest.

\section{Statement of informed consent}

Verbal consents were taken from patients' families.

\section{References}

[1] Osuorah CDI, Ekwochi U, Asinobi NI. Failure to establish spontaneous breathing at birth: A 5-year longitudinal study of newborns admitted for birth asphyxia in Enugu, Southeast Nigeria. 2018; 7 (3): 151-157.

[2] Motepalli A, Patel MR, Rao V. Birth asyphxia: Looking at trends of risk factors leading to birth asphyxia in a peripheral hospital. 2018; 7 (4): 245-248.

[3] Lafta AM, Yousif MK, Manther AA. Levels of liver enzymes in full-term neonates with perinatal asphyxia. 2019; 24(3): 191-196.

[4] Alemu A, Melaku G, Abera GB, Damte A. Prevalence and associated factors of perinatal asphyxia among newborns in Dilla University referral hospital, Southern Ethiopia-2017. Pediatric Health Med the. 2019; 10: 69—74.

[5] WHO; Word Health Statistics: Part II Global health indicators. 2015.

[6] WHO. Word health statistics: part I global health indicators. 2015.

[7] WHO. Word health statistics: part I global health indicators. 2015.

[8] WHO. Global health observatory data repository world health organization. 2015.

[9] Meshram RM, Bokade CM. Risk factors for mortality in birth asphyxia of outborn neonates: A prospective observational study. Sri Lanka Journal of Child Health. 2019; 48(1): 26-32.

[10] Committee on Fetus and Newborn; American Academy of Pediatrics; Committee on Obstetric Practice; American College of Obstetrician and Gynecologists. Use and abuse of the Apgar score. Pediatrics. 1996; 98: 141-2.

[11] Singh J, Poonia AK. Liver Dysfunction in Perinatal Asphyxia. IJNMR. 2019; 7(3): P006 - P008.

[12] Choudhary M, Sharma D, Dabi D. Hepatic dysfunction in asphyxiated neonates: prospective case-controlled study. Clin Med Insights Pediatr. 2015: 9: 1-6. 
[13] NNPD Network, Indian Council of Medical Research, National Neonatology Forum (India). National neonatalperinatal database: report 2002-2003. New Delhi: Nodal Centre, AIIMS. 2005.

[14] Saboute M, Mohaddes G, Mazouri A, Hoseinynejad N, Khalesi N. Liver impairment among neonates with moderate to severeAsphyxia. IJCA. 2017; 3(2): 10-13.

[15] Paliwal P, Varma M, ShaikhM, Mulye S, et al. Study of hepatic function in neonatal asphyxia. JEMDS. 2013; 2(31): 5764-5767.

[16] Chhavi N, Zutshi K, Singh N K, Awasthi A, Goel A. Serum liver enzyme pattern in birth asphyxia associated liver injury. PGHN. 2014; (3): 162-169.

[17] El-Kabbany Z, Hamza R, Toaima N. Early Hepatic Dysfunction in Asphyxiated Full Term Newborns. J Gastroenterol. 2017; 3(2): 1008s1. 